\title{
A study of liquid wastes disposal for metropolitan Athens and Piraeus
}

\author{
H. R. OAKLEY, K. D. STAPLES \& S. D. MYERS
}

\section{Mr Oakley, Mr Staples and Mr Myers}

The Paper describes in $\S 46$ the master plan proposal as submitted in December 1978. Since then, circumstances have changed in two important respects. A decision has been taken to re-site the international airport to the south-east of Athens, so the existing site at Ellinikon is likely to be available for urban development. Secondly, although the existing main outfall sewer to the proposed treatment works at Akrokeramos is adequate for the present, it will not be sufficient for the development expected in the future, and there are strong political objections to the construction of a duplicate sewer through this densely populated area of the city.

90. This has led to consideration of an alternative plan in which treatment and discharge from Akrokeramos would be limited to the flow and population that can be served by the existing main sewer, and the remainder of the population would be served by treatment works at Metamorphosis and at Ellinikon.

91. As already noted, disposal of septic tank sludge is a serious problem, and the Greek Government has therefore decided that the first stage in the implementation of the proposals will be the construction of a treatment facility for septic tank sludge at Metamorphosis so designed that it can be extended later to treat sewage to a high standard for discharge to a surface water channel. The next stage will be the development of partial treatment works at Akrokeramos for a population of 2.68 million and a maximum flow of $15 \mathrm{~m}^{3} / \mathrm{s}$, designed for discharge through a long sea outfall to be constructed at a later date. In this way the option is retained of constructing treatment works at Ellinikon to serve an ultimate population of 665000 , and of sewage treatment at Metamorphosis for a population of 816000 , as an alternative to concentrating all the sewage at Akrokeramos. The final decision need not be taken until the main outfall is constructed.

\section{The Chairman. Mr R. W. Horner}

With regard to the long outfall which is recommended, what about maintenance? It seems to me that once it is in operation, it will be extremely difficult to turn it off and to get in and maintain it. Can one discharge sewage locally for a short period without too much trouble? 
Mr P. Ackers, Binnie \& Partners

I wonder to what extent the mathematical model of water movement was used in assessing the convection and dispersion of the flow from the outfall, and how much reliance was placed on observed water movements.

94. The Paper refers to the importance of differing weather and climatic conditions, and factors such as the generation of currents due to wind stress. In the UK we have become used to the idea that tides are the forcing function, and that factors such as wind stress are secondary. In the Aegean the tides are minimal, and one is looking at other factors that affect water movement, and at behaviour such as stratification. Quite a sophisticated mathematical model would be needed to cover all these factors.

95. Frequently it is difficult to design an outfall to be self-cleansing, because of the diurnal variation of discharge, and because the outfall may be designed for future flows which may be double the present flows. It would be interesting to know the criteria that were applied. Was there, for example, a limiting velocity, and how would such a velocity be achieved in relation to the varying flow?

\section{Mr P. A. Banks, John Taylor \& Sons}

I wonder whether the Authors would enlarge on the intriguing aspects of local politics and sewerage. Recently a certain film star who mixes that profession with politics (as others do nowadays) damaged her head in riots which were said to be due to the population being disturbed at the lack of progress on sewerage by the government. It is a fairly unusual state of affairs: in the UK it is said that there are no votes in sewerage.

97. Referring to $\$ 4$ of the Paper, presumably the treatment works site at Rentis which was considered would have discharged to a watercourse that would be dry in the summer. What level of treatment was envisaged there?

\section{Mr J. W. Hill, Allott \& Lomax}

As I understand it from the text of the Paper, a considerable part of the central area of Athens is drained on the combined system, and it is not proposed to separate this. One would therefore expect to have a considerable variation in the flow, and a large multiple of dry weather flow in storm time; I wonder if the Authors would elaborate on the arrangements for dealing with this. Is the whole flow taken through the outfall? Is there a storm sewage overflow, and if so where is this sited? How does one deal with the variation of flow through the sewage disposal works?

99. I was surprised on reading the Paper to find such a vast increase in the Piraeus area draining to the natural watercourses, and that these were capable of taking the whole of the flow. Would the Authors give some information on the maximum rainfall intensities used in the design, and also the impermeability factors, which one would assume must be approaching $100 \%$.

\section{Mr P. C. Edwards. Thames Water Authority}

Concerning the disposal of sludge to land, it is said in the Paper (\$ 84) that agricultural use on a sufficient scale was not acceptable. Would the Authors care to comment on the reasons for this; and also on whether there is a role for large-scale use of sewage sludge in re-afforestation in the Athens area? 
Mr D. G. M. Roberts, John Taylor \& Sons

In studies such as this, what intrigues me is which alternatives are considered and which are rejected. If the nearest agricultural area is $60 \mathrm{~km}$ away, is this because of the lack of water in the Greater Athens area, and would a feasible alternative have been to purify the sewage and develop a new agricultural area closer to Athens?

102. Concerning the utilization of digested sludge, in Bagdad the sludge from nearly a million people has been used for 15-20 years on agricultural land, and there is an insatiable demand for it. I believe that similar techniques could also be used in other parts of the Middle East and the Mediterranean.

103. Concerning diffusers, in UK waters these rely mainly on currents to remove the sewage field away from the point of outfall, but in the Mediterranean the currents are much smaller, and I should like to know what thought has been given to modifications to the conventional design of diffusers to cope with the Mediterranean situation.

\section{Mr J. A. Pickford, University of Technology. Loughborough}

For the part of Athens to be dealt with by unsewered sanitation, if the 1200 tankers are operated by private enterprise contractors, are these contractors in competition and does this account for the low cost of the collection? Does it also result in a satisfactory clearance of septic tanks, or do the tankers skim off the top, as is common practice with municipal tankers?

105. As regards the disposal of the effluent from the septic tanks, a limit has been set of 150 people per hectare. Yet the sewage flow from the rich is at present more than three times the sewage flow from the poor. If there are 150 rich people producing more than three times as much effluent, does this mean that they are causing more trouble and more difficulty in disposing of the effluent, or is it quite safe, and is there really no trouble with disposal? Is the ground so permeable that it will take any amount, or is it impermeable? In the former case, why set a limit of 150 ? In the latter, with the increase of water usage in the past 30 years, do you expect trouble?-as, for example, has occurred in Tehran, where there is sewage flowing out into the streets, having been disposed of in the higher and more affluent parts of the town.

\section{Mr A. R. Agg, Water Research Centre}

The proposals, which will undoubtedly lead to considerable improvement of nearshore water quality, include the disposal of sewage sludge in the Mediterranean Sea $25 \mathrm{~km}$ from the nearest land. In view of the considerable international pressures to limit or abandon disposal of sewage sludge to sea, can the Authors say if there has been any reaction to this part of the proposals from the World Health Organisation or officials of the United Nations Development Programme since both organisations are involved in the co-operative venture?

\section{Mr K. Richards, Lothian Regional Council}

The Paper has been read with great interest as the scheme bears many similarities to a scheme which is nearing completion for the City of Edinburgh and the adjoining urban area.

108. As is usual with a project of this type engineers are faced with formidable restraints and a substantial number of permutations of solutions to the problems. 
The Authors are therefore to be congratulated on presenting from the mass of unrelated information a Paper which summarizes the main constraints and an acceptable solution.

109. Further information is requested as to the high standards for water quality objectives. In particular why was a $30: 20$ standard considered necessary for the airport site when a long sea outfall was planned? It is considered that the real problem involves the bacteria count. For the Keratsini site what were the reasons for proposing a 50:50 standard? In addition for what reasons was disinfection considered necessary and what type of treatment was proposed?

110. As at Edinburgh it is interesting to note that the chosen scheme involved a long outfall following primary treatment. Is any information available as to the relationship between the peak flow and the dry weather flow?

111. It is felt that sludge digestion should be treated with caution until a tradition of trade effluent control has been built up and its effectiveness demonstrated. Frequent accidental discharges of toxic matter can be catastrophic even with multiple digestors. It is appreciated that digestion assists consolidation, but can digestion really be justified prior to disposal by sea? In this connection was a costing exercise carried out and what sludge storage capacity was planned?

\section{Mr A. W. Shilston, Consulting Engineer}

Water pollution control engineering generates an increasing number of matters that call for consideration in the design synthesis, and in an overseas context the political ingredient could be significant. It is an aspect of total design that ought to be freely discussed.

113. Would the Authors say how dominant was the political factor in their study activities; and what was the extent of the political insights and perceptions which were needed within the study team aggregate resource during the process of synthesis?

114. Would the Authors please enlarge on the project management and control arrangements needed in the Athens liquid wastes disposal comprehensive study, describing broadly their working relationships with Government agencies and their joint venture collaborators. What was the division of responsibility for the field work and how many expatriates from the Authors' firm were based in Athens? Who instructed the outside consultants mentioned in $\S 86$ and to whom did they report?

\section{Mr Oakley, Mr Staples and Mr Myers}

We agree that maintenance of a long sea outfall is an important aspect of the design. The proposed pretreatment works would remove most of the settleable solids, and the outfall was designed for a velocity at minimum flow of $0.3 \mathrm{~m} / \mathrm{s}$ and is expected to be virtually self-cleansing. Inspections would take place in the wet or by remotecontrolled TV, but if planned or emergency repairs required dry access, temporary discharge would be made at the treatment works or from one of the working shafts.

116. The mathematical model referred to in the Paper was directed towards describing the basic pattern of movement in the Saronic Gulf in response to baroclinic changes, wind stress, stratification and interaction from adjacent water masses. It was not sufficiently detailed to model effiuent movement and dispersal and it is considered that it would not have been practicable to develop the model for this purpose. Reliance was therefore placed on the additional fieldwork described in the Paper, from which predictions were made of water movement local to the proposed 
points of outfall. Conventional diffuser systems were proposed, designed to give high initial dilutions, resulting from density differences and the depth below surface.

117. The effluent standards proposed were related in part to aesthetic considerations; in part to the need to avoid accumulation of settleable solids on the sea bed adjacent to the outfall; and in part to the bacterial standards for bathing beaches. It was the latter which necessitated disinfection before discharge through the proposed Keratsini outfall, and both chlorine and ozone methods were considered. The higher standard proposed for the airport site was related to the shallow water and the lower initial dilution possible at this point on the coastline. Where effluent from inland works discharges to dry water courses a very high standard of effluent will be required, of the order of $10 \mathrm{mg} / \mathrm{l} \mathrm{BOD}$ and $10 \mathrm{mg} / \mathrm{l} \mathrm{SS}$ followed by chlorine or other treatment to disinfect.

118. Concerning surface water drainage, the area served by the combined sewer system is quite small, but there are storm overflows which discharge to the surface water drainage system, and reconstruction of some of these was proposed to improve the hydraulics and incorporate screens. The flows to the treatment works would then be restricted to $24.4 \mathrm{~m}^{3} / \mathrm{s}$, all of which would pass through sedimentation tanks, which would provide 45 min retention at this rate of flow. The main effluent outfall capacity would be limited to $19.8 \mathrm{~m}^{3} / \mathrm{s}$, and the balance would be passed to sea through a supplementary short outfall. In estimating surface water run-off, impermeability factors were used for urban areas related to population density and these varied from 0.3 to 0.9 ; for rural areas the factors varied from 0.1 to 0.6 depending on the slope and character of the terrain. Rainfall intensities have been studied by others and intensity-duration-frequency curves drawn up on the basis of statistical analysis of data. Examination of these curves led to the conclusion that for durations of over $1 \mathrm{~h}$ the intensity could be expressed as $12 \cdot 8 R^{1 / 3} t^{-2 / 3}$ (where $R$ is the return period in years and $t$ the duration in hours). For rainfall of lesser duration curves were derived by a method corresponding to the Gumbel type of treatment of Bilham's formula. Adjustments were also made for increased intensity of point rainfall for small catchments.

119. The whole project has been assisted by periodic consultation with a World Health Organisation technical panel who raised no objection to the principle of sludge disposal to sea. We take the view that it would be prudent to establish alternative means of sludge disposal to land or to sea, for use as circumstances dictate. We believe that the anaerobic digestion and screening of sludge before disposal to sea is justified to safeguard against odour nuisance, and as a means of reducing the quantity of organic matter, grease and identifiable solids. It is also a buffer against the accidental discharge of toxic solids; it is considered better to lose digestion if these circumstances arise, rather than risk a toxic discharge to sea. Sludge storage capacity of up to 3 days was proposed to cover adverse weather, breakdown, holidays and other contingencies. The capital and annual costs of alternative methods of sludge disposal were considered in some detail.

120. In regard to the agricultural use of sludge, there is an extensive reafforestation programme to the east of Athens and the use of sludge in this area was recommended, although it would absorb only a small proportion of the total quantity expected. Particular attention was paid in the study to the feasibility of using effluent for irrigation, but the nature of the subsoil, the possible crops, the economy of the country and the difficulties of control, including health risks, led to the firm conclusion that this would not be an attractive or economic alternative.

121. Concerning the problems of using septic tanks, no doubt competition 
between private enterprise contractors is responsible for the low cost of emptying the tanks, but equally tends to result in unsatisfactory clearance. The debate on the relative efficiency and reliability of public and of private institutions is as lively in Greece as elsewhere. The population density at which sewage becomes economic in areas of high subsoil porosity is related to the cost of emptying sludge from the septic tanks as well as to the sewage flow, and it was assumed that the quantity of solids per capita discharged from septic tanks would be similar for all income groups. Problems similar to those experienced in Tehran were not expected in Athens due to the different topological and hydrological conditions.

122. A basic team of four expatriates was resident in Athens for most of the study period, working in the office of their Greek colleagues and in close collaboration with them, and assisted by visiting specialists. Arrangements with Government organizations were made through the good offices of the client, the Ministry of Public Works. Sub-consultants were instructed in the normal way and were responsible to the main consultant. Work in Athens was carried out under the direction of the resident Project Manager, but partners based in the UK determined policy and guided the work. Programme control was achieved through PERT-type diagrams, and financial control by monthly budget reviews.

123. On the question of political influences, we feel that it is inappropriate to discuss this in a technical paper, other than to say that engineering cannot be divorced from human activities, and engineering solutions will always be properly influenced by social and political factors.

\section{Corrigendum}

Fig. 13 caption should read: Proposed sludge dumping area. 